\title{
Wyrównywanie szans edukacyjnych studentów z niepełnosprawnościami - 10 lat doświadczeń w Uniwersytecie Papieskim Jana Pawła II w Krakowie
}

Prawo do nauki jest jednym z fundamentalnych praw człowieka, którego realizacja umożliwia rozwój osobisty oraz pozwala na osiągnięcie samodzielności i niezależności, a także pełny udział we wszystkich sferach życia. Konstytucja Rzeczypospolitej Polskiej w art. $70^{1}$ przyznaje każdemu obywatelowi prawo do nauki oraz zobowiązuje władze publiczne do zapewnienia powszechnego i równego dostępu do wykształcenia. Wykształcenie jest pojęciem trudnym do precyzyjnego ujęcia definicyjnego. Można je określić jako rezultat procesu kształcenia i samokształcenia, zarówno w zakresie ogólnym, jak i specjalistycznym. Wykształcenie obejmuje też zasób opanowanej wiedzy o przyrodzie, społeczeństwie, technice i sztuce oraz sprawności i postawy, co umożliwia udział w życiu społecznym i wykonywanie zawodu ${ }^{2}$. Zgodnie $\mathrm{z}$ treścią Powszechnej Deklaracji Praw Człowieka (art. 26) ${ }^{3}$, prawo do nauki, w tym edukacji na poziomie wyższym, przysługuje wszystkim osobom niezależnie od rasy, wyznania czy niepełnosprawności. Z kolei w raporcie „Edukacja w zarysie”, który jest zbiorem danych o systemach edukacyjnych w krajach OECD i partnerskich, czytamy, że stale rośnie liczba

1 Konstytucja Rzeczypospolitej Polskiej z dnia 2 kwietnia 1997 r., Dz.U. 1997, nr 78, poz. 48.

2 W. Okoń, Słownik pedagogiczny, PWN, Warszawa 1981.

3 www.unesco.pl/.../Powszechna_Deklaracja_Praw_Czlowieka.pdf (dostęp: 23.06.2018). 
absolwentów wyższych uczelni, a im więcej lat spędzonych na edukacji, tym większa szansa na zatrudnienie i lepsze zarobki . Dla osób z niepełnosprawnościami, edukacja nie tylko pozwala zdobyć wiedzę, ale stanowi podstawowe narzędzie wyrównywania szans życiowych, oraz najważniejsze ogniwo rehabilitacji społecznej i zawodowej ${ }^{5}$. Ratyfikując Konwencję o prawach osób niepełnosprawnych ${ }^{6}$ Polska uznała prawo tej grupy osób do edukacji oraz zobowiązała się zapewnić włączający system kształcenia umożliwiający integrację na wszystkich poziomach edukacji. Rzeczpospolita zapewniła także, że osoby te będą miały dostęp do powszechnego szkolnictwa wyższego bez dyskryminacji i na zasadzie równości. Polityka inkluzji społecznej, a w szczególności edukacyjnej osób z niepełnosprawnościami jest odpowiedzią na rosnące potrzeby i aspiracje tej grupy osób i jednocześnie efektem zmiany poglądów, nastawień społecznych, dążenia do poprawy jakości życia i zwiększania możliwości efektywnego funkcjonowania osób z niepełnosprawnościami we współczesnym świecie. Jednym z warunków pełnego uczestnictwa w życiu społecznym i zawodowym osób z niepełnosprawnościami jest ich przygotowanie do wykonywania pracy zawodowej, a jednym z możliwych etapów tego przygotowania są studia wyższe.

Historia badań nad problemem niepełnosprawności wśród studentów, ich potrzeb oraz systemu ich zaspokajania jest stosunkowo krótka. Pierwsze polskie analizy przeprowadzone zostały pod koniec ubiegłego wieku. Momentem przełomowym okazały się inicjatywy międzynarodowe podkreślające wyjątkową rangę edukacji w życiu człowieka oraz upowszechnienie szkolnictwa wyższego w okresie transformacji ustrojowej. Funkcjonowanie osób niepełnosprawnych na uczelniach wyższych uregulowane jest w ustawie Prawo o szkolnictwie wyższym?

4 Education at a Glance 2012: OECD Indicators, OECD Publishing. http://dx.doi. org/10.1787/eag-2012-en (dostęp: 23.12.2019).

5 B. Szczupał, Młodzież niepełnosprawna wobec edukacyjno-zawodowej przyszłości, [w:] T. Żółkowska (red.) Pedagogika specjalna - koncepcje i rzeczywistość. Konteksty pedagogiki specjalnej, t. 2, Wydawnictwo Print Group Daniel Krzanowski, Szczecin 2007, s. 549-554.

6 Konwencja o prawach osób niepełnosprawnych sporządzona w Nowym Jorku dnia 13 grudnia 2006 r., ratyfikowana przez Prezydenta RP 6 września 2012 r. (Dz.U. 2012, poz. 1169).

7 Ustawa z dnia 18 marca 2011 r. o zmianie ustawy - Prawo o szkolnictwie wyższym, Dz.U. 2011, nr 84, poz. 455. 
Zgodnie z jej zapisami studentem studiów pierwszego stopnia i studiów jednolitych, może zostać każda osoba posiadająca świadectwo dojrzałości i spełniająca ogólne warunki rekrutacji. Prawo takie przysługuje również osobom niepełnosprawnym. Szkolnictwo wyższe jest jedynym poziomem edukacji, na którym nie ma specyficznych rozwiązań odnoszących się do osób niepełnosprawnych, tak jak ma to miejsce na niższych szczeblach poprzez edukację integracyjną i szkoły specjalne.

Decyzja o podjęciu nauki na wyższej uczelni stanowi przełomowy moment w życiu młodego człowieka. Pociąga ona za sobą szereg skutków zarówno fizycznych, jak i psychicznych, w szczególny sposób warunkujących jego dalsze losy. Staje się niejako przyczyną zmian „rozwojowych, edukacyjnych, społecznych, światopoglądowych”. Czas studiowania wzmaga wytwarzanie wśród młodzieży akademickiej pewnych predyspozycji do „moralnej refleksji i samodzielności rozumianej jako zdolność do samowychowania” oraz „rzetelnego” wypełniania zadań wynikających z roli studenta9. Ponieważ jest to okres pełniejszego dojrzewania, wchodzenia w dorosłość, młody człowiek, wkraczając w świat akademicki, zobowiązany jest do wzięcia odpowiedzialności za własne poczynania, realizacji obranych wcześniej celów, podejmowania szeregu decyzji dotyczących przyszłości ${ }^{10}$. W zależności od jakości i tempa wprowadzanych w życie zmian przebiegać będzie proces dopasowania się poszczególnych jednostek do nowo zastanej rzeczywistości. Ta „dynamika wspomnianych przeobrażeń zaznacza się w szczególny sposób na pierwszym roku studiów, ze względu na nowość większości sytuacji i towarzyszących im przeżyć"11.

Problemy, jakie stają się udziałem niepełnosprawnych studentów często mają bardzo indywidualny charakter, a ich złożoność może być

8 S. Byra, M. Parchomiuk, Osobowościowe i społeczne uwarunkowania radzenia sobie ze stresem przez studentów pierwszego roku, Wydawnictwo Uniwersytetu Marii $\mathrm{Cu}-$ rie-Skłodowskiej, Lublin 2009.

$9 \quad$ J. Sowa, Bezradność osoby niepetnosprawnej na tle przestrzeni życiowej, [w:] Z. Gajdzica, M. Rembierz (red.), Bezradność. Interdyscyplinarne studium zjawiska w kontekście zmiany społecznej i edukacyjnej, Wydawnictwo Uniwersytetu Śląskiego, Katowice 2005, s. 58.

10 Ibidem, s. 35.

11 S. Byra, M. Parchomiuk, Osobowościowe i społeczne uwarunkowania..., s. 7. 
bardzo różna. W charakterystyce tych trudności wyróżnić można kilka poziomów ${ }^{12}$ :

1. Problemy funkcjonalne - bariery architektoniczne, urbanistyczne, komunikacyjne i informacyjne. Najbardziej widoczne, bariery architektoniczne, utrudniają lub wręcz uniemożliwiają efektywne funkcjonowanie w przestrzeni akademickiej. Są przyczyną trudności w przemieszczaniu się, korzystaniu z konkretnych sal, czy jednostek administracji. Ich wpływ na funkcjonowanie studenta odnosi się do osób z ograniczeniami ruchowymi, ale także do osób z uszkodzeniami wzroku i niewidomych. Bariery komunikacyjne i informacyjne natomiast dotyczą osób słabo słyszących, głuchych i osób z problemami w komunikacji werbalnej (porażenia aparatu mowy, jąkanie). Skutkiem funkcjonowania tych barier może być ograniczanie kontaktów społecznych, trudności w ustnych zaliczeniach, ograniczenia samodzielnego załatwienia spraw związanych ze studiowaniem w jednostkach administracji uczelni;

2. Problemy edukacyjne - na które składać się mogą problemy z pozyskiwaniem, rozumieniem, opanowaniem i wykorzystaniem wiedzy i umiejętności zdobywanych w trakcie procesu edukacji. Wpływ problemów edukacyjnych znacząco wpływa na poczucie własnej wartości i samoocenę jednostki;

3. Problemy psychospołeczne-wynikające $\mathrm{z}$ negatywnych postaw środowiska i stereotypów dotyczących osób niepełnosprawnych. Zdarzają się sytuacje unikania osób niepełnosprawnych przez osoby sprawne w pełni. Powodowane może to być lękiem przed kontaktem z osobą z niepełnosprawnością (nie wiadomo co powiedzieć, jak zareagować na wygląd fizyczny, częsty jest także strach przed „zarażeniem” się chorobą).Zdarza się, że defekt fizyczny wywołuje negatywne komentarze i śmiech. Wygląd fizyczny może też skłaniać do wydawania negatywnych sądów o cechach charakteru osób niepełnosprawnych. Społeczne funkcjonowanie studentów niepełnosprawnych łączyć się może z etykietowaniem i stygmatyzacją. Pierwszy mechanizm powo-

12 S. Byra, Percepcja wsparcia i osoby wspierajacej studentów niepetnosprawnych, [w:] S. Byra, M. Parchomiuk (red.), Student niepelnosprawny - wybrane konteksty, Wydawnictwo Uniwersytetu Marii Curie-Skłodowskiej, Lublin 2010, s. 17-20. 
duje ujawnianie swoich deficytów w celu uzyskania wsparcia, co jest zjawiskiem pozytywnym. Uzyskanie etykiety niepełnosprawnego może jednak wywołać społeczną stygmatyzację, odrzucanie lub negatywne odróżnianie danego człowieka od całej grupy społecznej ${ }^{13}$;

4. Problemy ekonomiczne - funkcjonowanie ekonomiczne osób niepełnosprawnych zazwyczaj jest ograniczone przez specyfikę danej choroby. W związku z tym wydatki ponoszone comiesięcznie na leczenie istotnie uszczuplają budżet. Może być to powodem rezygnacji ze studiowania lub w ogóle braku chęci podjęcia kształcenia w szkole wyższej. Dążenie do osiągnięcia wyższego wykształcenia jest przejawem zaspokajania przez jednostkę potrzeby samorealizacji, uznania, bezpieczeństwa. Zdobycie dyplomu uczelni wyższej podwyższa często samoocenę i poczucie własnej wartości. Człowiek czuje się pewniej, ma większe możliwości znalezienia satysfakcjonującej go pracy. Osoby niepełnosprawne ruchowo również marzą o spełnieniu się w pewnych dziedzinach. Dlatego ukończenie studiów często jest priorytetem w ich życiu. Udowadniają swojemu otoczeniu, że potrafią osiągać cele, że mogą pracować i sami zapewnić sobie byt na należytym poziomie. Wyższe wykształcenie pozwala na zaspokojenie potrzeb intelektualnych i wielu potrzeb społecznych ${ }^{14}$.

Sieć szerokiego wsparcia studentów z niepełnosprawnościami jest coraz lepiej skonstruowana, przemyślana i wzmacniana różnymi doświadczeniami, co skutkuje osiąganiem przez nich coraz lepszych wyników edukacyjnych. Systematycznej poprawie ulegają warunki studiowania, dostępność specjalistycznego sprzętu i oprogramowania, powoli znikają bariery architektoniczne i w komunikowaniu się. Ma to przełożenie na liczbę studiujących osób z niepełnosprawnościami, która od kilku lat systematycznie wzrasta. Rosnącym aspiracjom młodych ludzi towarzyszy polityka uczelni nastawiona na usprawnianie procesu kształcenia studentów z różnorodnymi ograniczeniami sprawności. W celu wzmocnienia gwarancji edukacji bez dyskryminacji

13 Ibidem, s. 17-20.

14 J. Szempruch, Edukacja wobec wyzwań i zadań współczesności i przyszłości: strategie rozwoju, Wydawnictwo Uniwersytetu Rzeszowskiego, Rzeszów 2006. 
i na zasadzie równych szans w roku 2011 przeprowadzono nowelizację ustawy - Prawo o szkolnictwie wyższym. Zakłada ona stworzenie osobom $z$ niepełnosprawnościami warunków do pełnego udziału w procesie kształcenia i badaniach naukowych - co uczyniono jednym z podstawowych zadań uczelni. Tak więc stwarzanie pełnych warunków do studiowania osobom $\mathrm{z}$ niepełnosprawnościami stało się jednym z najważniejszych wyzwań stojących przed polskimi uczelniami.

Na wzrost liczby osób niepełnosprawnych podejmujących studia wyższe składa się wiele zmian, które zaszły zarówno w przestrzeni edukacyjnej szkół wyższych, jak i w systemie polityki społecznej państwa względem osób niepełnosprawnych. Rozwiązania prawne pod postacią wprowadzenia stypendiów specjalnych dla studentów z niepełnosprawnościami ${ }^{15}$, dotacji dla uczelni państwowych przeznaczanych celowo na kształcenie studentów niepełnosprawnych ${ }^{16}$ czy program Aktywny samorząd (dawniej Student - pomoc osobom niepełnosprawnym w zdobyciu wykształcenia na poziomie wyższym i Student II - kształcenie ustawiczne osób niepełnosprawnych) realizowany przez Państwowy Fundusz Rehabilitacji Osób Niepełnosprawnych, z całą pewnością wpłynęły na bardzo szybkie zwiększenie się liczby studentów z niepełnosprawnościami w Polsce, aż do 2012 roku. Od roku 2013 można zaobserwować nieznaczny spadek liczebności populacji niepełnosprawnych studentów, ale fakt ten należy powiązać z aktualną sytuacją demograficzną - ogólnym spadkiem liczebności populacji kandydatów na studentów - tzw. niżem demograficznym.

Naturalną konsekwencją wzrostu liczebności populacji studentów z niepełnosprawnościami na polskich uczelniach wyższych, jest wzrost liczby absolwentów niepełnosprawnych, którzy opuszczają mury uczelni wyższych. Na podstawie wyników badań prowadzonych przez E. Giermanowską i zespó ${ }^{17}$ sformułowano tezę o powstaniu „nowego problemu społecznego", będącego efektem wzrostu aspiracji edukacyjnych osób niepełnosprawnych przy trudnościach w wejściu na rynek pracy. Wyniki te wskazują, że niepełnosprawni absolwenci

15 Ustawa z dnia 27 lipca 2005 r. - Prawo o szkolnictwie wyższym, Dz.U. 2005, nr 164, poz. 1365 , art. 173.

16 Ibidem, art. 94.

17 E. Giermanowska, A. Kumaniecka-Wiśniewska, M. Racław, E. Zakrzewska-Manterys, Niedokończona emancypacja. Wejście niepełnosprawnych absolwentów szkół wyższych na rynek pracy, Wydawnictwa Uniwersytetu Warszawskiego, Warszawa 2015. 
szkół wyższych stanowią grupę potencjalnie bardzo wartościowych pracowników - to grupa niezwykle silnie zmotywowana do pracy, mobilna i nauczona pokonywać przeciwności losu. Zdobyciu wykształcenia wyższego nie towarzyszy jednak adekwatna usługa w postaci doradztwa i informacji zawodowej czy zatrudnienia na otwartym rynku pracy, brakuje także profesjonalnie przygotowanych instytucji wspierających młodych niepełnosprawnych w poszukiwaniu zatrudnienia i działań promujących zatrudnienie niepełnosprawnych wśród pracodawców $^{18}$.

Efektem takiego stanu rzeczy jest „niska efektywność zatrudnieniowa", która utrzymuje się od wielu lat, pomimo wprowadzania i intensyfikowania wielu działań, które mają na celu poprawę sytuacji osób z niepełnosprawnościami na rynku pracy. Z badań H. Żuraw ${ }^{19}$ nad stylami życia ludzi niepełnosprawnych fizycznie wynika, że studia wyższe zwiększają szanse zatrudnienia, ale go nie gwarantują. Osoby niepełnosprawne po studiach zwykle podejmują każdą oferowaną im pracę. Rzadko udaje im się uzyskać pracę zgodną z kierunkiem i poziomem wykształcenia. Warto podkreślić, że posiadane wykształcenie różnicuje aktywność zawodową osób niepełnosprawnych - istnieje powiązanie: im wyższy poziom wykształcenia posiadanego przez osoby niepełnosprawne, tym wyższy współczynnik aktywności zawodowej tych osób, jak też wskaźnik zatrudnienia. Najwyższą aktywnością zawodową cechują się osoby z wyższym i średnim poziomem wykształceniem.

Wiele osób z niepełnosprawnościami doświadcza czasowych lub stałych trudności w relacjach ze społecznością akademicką. Problemem przytaczanym wielokrotnie przez badaczy zajmujących się tym tematem studiów wyższych osób z niepełnosprawnościami są bariery mentalne. Wiele kwestii z otoczenia społecznego osób niepełnosprawnych ulega zmianie (np. likwidacja barier architektonicznych) niestety „to właśnie bariery mentalne, związane z negatywnymi postawami wobec niepełnosprawnych, są często uważane za podstawę wszystkich innych barier. Stereotypowe podejście do osób niepełnosprawnych jest jednak trudne do zniwelowania, wymaga bowiem zmiany ich

18 Ibidem, s. 8.

19 H. Żuraw, Udział osób niepełnosprawnych w życiu społecznym, Wydawnictwo Akademickie Żak, Warszawa 2008. 
postrzegania przez całe społeczeństwo" ${ }^{20}$. Żadna idea nie jest bowiem $\mathrm{w}$ stanie zmienić $\mathrm{w}$ przeciągu nawet kilkudziesięciu lat mentalności ludzi, ich lęków wobec odmienności i ich irracjonalnych postaw, nawet w środowisku tak postępowym jak środowisko akademickie. W tym miejscu warto przytoczyć wyniki badań prowadzonych przez Struck-Peregończyk ${ }^{21}$, z których wynika, że osoby o dłuższym stażu pracy na uczelni (czyli starsze) mają mniej pozytywne nastawienie wobec studentów niepełnosprawnych.

W kompetencji uczelni wyższych pozostaje większość instrumentów pomocy osobom niepełnosprawnym w podjęciu i kontynuowaniu nauki. Wiele z nich wypracowało kompleksowy i trwały model wsparcia kierowany wyłącznie do swoich niepełnosprawnych studentów. Aktualnie w polskim systemie publicznego i niepublicznego szkolnictwa wyższego student $\mathrm{z}$ niepełnosprawnością może korzystać niejako z dwu źródeł wsparcia. Pierwsze źródło to wsparcie udzielane na zasadach ogólnych - dostępne dla wszystkich osób posiadających status studenta, drugie to wsparcie przyznawane z tytułu niepełnosprawności.

Zgodnie z ogólnymi przepisami ustawy z 2011 r. o szkolnictwie wyższym, każdy student ma prawo m.in. do swobodnego wyboru kierunku studiów, do nauki według indywidualnego toku lub programu nauczania oraz do urlopowania ${ }^{22}$. Każdy student (także niepełnosprawny) może uzyskać pomoc materialną ze środków publicznych. Zależnie od jego sytuacji materialnej ubiegać się może o przyznanie odpowiedniego stypendium, w tym stypendium socjalnego, na wyżywienie, mieszkaniowego oraz zapomogi. $Z$ budżetu państwa finansowane są ponadto stypendia przeznaczone dla studentów posiadających szczególne osiągnięcia, w tym stypendium za wyniki w nauce lub sporcie oraz ministerialne stypendia za wybitne osiągnięcia w nauce i sporcie $^{23}$.

20 M. Struck-Peregończyk, Podstawy kadry akademickiej wobec studentów niepełnosprawnych. Studium przypadku Wyższej Szkoły Informatyki i Zarządzania w Rzeszowie, [w:] B. Gąciarz (red.) Niepełnosprawni studenci w społeczności akademickiej. Źródła sukcesów i porażek w integracji społecznej i aktywności zawodowej, Wydawnictwo IFiS PAN, Warszawa 2010, s. 147-163.

21 Ibidem, s. 153.

22 Ustawa z dnia 18 marca 2011 r. o zmianie ustawy Prawo o szkolnictwie wyższym, Dz.U. 2011, nr 84, poz. 455, art. 171 i 172.

23 Ibidem, art. 173. 
Oddzielnym źródłem wsparcia dla studentów z niepełnosprawnościami, są środki finansowe ministerstwa nauki i szkolnictwa wyższego przekazywane uczelniom państwowym (od 2007 roku) i uczelniom niepublicznym (od 2011 roku) w postaci dotacji celowej na zadania związane ze stwarzaniem studentom i doktorantom, będącym osobami niepełnosprawnymi warunków do pełnego udziału w procesie kształcenia (wcześniej: kształcenie i rehabilitację leczniczą studentów niepełnosprawnych), [Ustawa z dnia 18 marca 2011 r. o zmianie ustawy - Prawo o szkolnictwie wyższym, art. 94, pkt 11].

W związku z dysponowaniem przez uczelnie środkami finansowymi przeznaczonymi na wspieranie kształcenia studentów i doktorantów z niepełnosprawnościami, w znacznej części uczelni został zorganizowany system wsparcia studentów niepełnosprawnych. W większości uczelni zajmują się tym konkretne jednostki. Jak wynika z raportu Formy wspierania studentów z niepełnosprawnościami w szkołach wyższych w Polsce. Raport z badania polskich uczelni ${ }^{24}$ ponad połowa uczelni jako jednostkę wspierającą studentów z niepełnosprawnościami w procesie studiowania wskazała bądź ogólną jednostkę zajmującą się sprawami studenckimi (52\%) bądź wyspecjalizowaną jednostkę - najczęściej Biuro ds. Osób Niepełnosprawnych (57\%). Respondenci wskazali też, że osobami odpowiedzialnymi za wspieranie studentów niepełnosprawnych na uczelniach są również:

- pracownicy dydaktyczni (19\%);

- wyspecjalizowani pracownicy - psycholog, pedagog specjalny, logopeda, terapeuta (18\%).

Funkcje taką na uczelniach mogą pełnić również - Pełnomocnik Rektora ds. Osób Niepełnosprawnych, wydziałowi opiekunowie/koordynatorzy ds. Osób Niepełnosprawnych, doradca zawodowy z Biura Karier, Studencki Rzecznik Osób Niepełnosprawnych, a nawet dyrektor biblioteki czy administrator budynku.

W 2007 roku w Uniwersytecie Papieskim Jana Pawła II w Krakowie (UPJPII) powołano Pełnomocnika Rektora ds. Osób Niepełnosprawnych, a w 2008 roku Biuro ds. Osób Niepełnosprawnych (BON). Wsparcie oferowane studentom finansowane jest ze środków własnych

24 J. Sztobryn-Giercuszkiewicz, Formy wspierania studentów z niepełnosprawnościami w szkołach wyższych $w$ Polsce. Raport z badania polskich uczelni, Wydawnictwo Uniwersytetu Łódzkiego, Łódź 2015. 
uczelni oraz z celowej dotacji ministerstwa nauki i szkolnictwa wyższego. Naczelną zasada, którą BON UPJPII kieruje się w udzielaniu pomocy jest wyrównywanie szans edukacyjnych poprzez stwarzanie możliwości pełnego uczestnictwa bez obniżania wymagań edukacyjnych wobec studentów z niepełnosprawnościami.

Procentowy udział osób z niepełnosprawnościami w kształceniu w Uniwersytecie Papieskim Jana Pawła II w Krakowie to około 4\%. Do najczęściej zgłaszanych przez studentów tej uczelni niepełnosprawności zalicza się: niepełnosprawność ruchową, psychiczną oraz sensoryczną (zaburzenia wzroku). Ponadto, coraz częściej w Uniwersytecie studiują osoby z Zespołem Aspergera.

Do form wsparcia, jakie oferuje Biuro ds. Osób Niepełnosprawnych UPJPII należą przede wszystkim:

- specjalistyczny sprzęt w bon, bibliotekach i do użytku indywidualnego;

- lektoraty indywidualne i dodatkowe;

- usługi tłumacza języka migowego;

- asystenci dydaktyczni;

- alternatywne zajęcia wychowania fizycznego;

- obozy adaptacyjne;

- konsultacje psychologiczne i doradczo-zawodowe;

- warsztaty;

- dostosowanie materiałów dydaktycznych;

- zajęcia orientacji przestrzennej;

- codzienna pomoc w procesie studiowania;

- zamiana formy egzaminu;

- likwidacja barier architektonicznych i w komunikowaniu się, zajęcia w salach dostosowanych.

Biuro ds. Osób Niepełnosprawnych UPJPII należy do Porozumienia o współpracy biur ds. osób niepełnosprawnych krakowskich uczelni. Idea porozumienia zrodziła się na gruncie nieformalnych spotkań pełnomocników rektorów ds. osób niepełnosprawnych, działających na poszczególnych uczelniach. Podstawowym celem przyświecającym twórcom było przezwyciężanie administracyjnych barier we wspólnym wdrażaniu kolejnych projektów. Po raz pierwszy porozumienie o współpracy podpisane zostało 15 listopada 2007 roku przez rektorów trzech uczelni: Akademii Górniczo-Hutniczej, Politechniki Krakowskiej oraz Akademii Ekonomicznej (obecnie Uniwersytet 
Ekonomiczny). Dwa lata później (kwiecień 2009 roku) do porozumienia przystąpiły też: Uniwersytet Pedagogiczny i Uniwersytet Papieski Jana Pawła II w Krakowie, w październiku 2010 roku do tego grona dołączył Uniwersytet Jagielloński. W następnych latach porozumienie rozszerzyło się o Uniwersytet Rolniczy (2015), Krakowską Akademię im. A. Frycza-Modrzewskiego (2017) oraz Urząd Miasta Krakowa (2019). Podpisanie przez rektorów najbardziej znaczących uczelni Krakowa, porozumienia o wspólnej działalności na rzecz studentów z niepełnosprawnościami, przyczyniło się do wzrostu zainteresowania tematyką niepełnosprawności w środowisku akademickim i poprawiło sytuację studentów borykających się z problemem niepełnej sprawności.

Sygnatariusze porozumienia zobowiązali się do podejmowania wspólnych działań na rzecz studentów niepełnosprawnych, a w szczególności do:

- prezentowania wspólnego stanowiska w omawianych kwestiach na forum ogólnopolskim;

- międzyuczelnianej wymiany doświadczeń;

- polepszania warunków kształcenia osób niepełnosprawnych;

- wspólnego występowania o środki finansowe na realizację wspólnych przedsięwzięć;

- organizowania wspólnych imprez mających na celu integrację osób niepełnosprawnych w środowisku akademickim;

- wspólnych przedsięwzięć podnoszących kwalifikacje zawodowe studentów niepełnosprawnych i podnoszące ich konkurencyjność na rynku pracy;

- wspólnego organizowania zajęć wychowania fizycznego oraz zajęć rehabilitacyjnych $\mathrm{z}$ wykorzystaniem baz sportowych poszczególnych uczelni ${ }^{25}$.

Charakter i zakres porozumienia stanowi pewną podstawę do pracy, wyznacza kierunki wsparcia niepełnosprawnych studentów. Całością zadań związanych z pomocą niepełnosprawnym studentom zajmują się odpowiednie struktury działające na uczelniach, są nimi pełnomocnicy rektora ds. osób niepełnosprawnych oraz biura ds. osób niepełnosprawnych (BON-y) i działy ds. osób niepełnosprawnych. Całości systemu wsparcia oferowanego studentom z niepełnosprawnościami na poszczególnych uczelniach Krakowa jest bardzo bogata

$\overline{25}$ Ibidem, s. 28-31. 
i dotyczy różnych sfer - tak codziennego funkcjonowania i jak i szerszej perspektywy przygotowania do samodzielnego funkcjonowania w społeczeństwie, w tym podejmowania pracy zawodowej.

W ramach współpracy organizowane są różnego rodzaju wydarzenia dla studentów i doktorantów z niepełnosprawnościami, np.: Krakowskie Dni Integracji, obozy sportowe, Ogólnopolskie Spotkania Studentów Niepełnosprawnych. W ramach Porozumienia powstało także Międzyuczelniane Centrum Wsparcia Psychologicznego, oferujące konsultacje specjalistyczne, terapie, warsztaty oraz szkolenia dla pracowników uczelni.

Wśród działań na rzecz studentów z niepełnosprawnościami, wymienianych przez przedstawicieli szkół wyższych, a przytaczanych w raporcie Formy wspierania studentów z niepełnosprawnościami w szkołach wyższych w Polsce ${ }^{26}$, na pierwszym miejscu znalazła się pomoc materialna - 93\% respondentów wskazało tę formę wsparcia. Jest to zarówno stypendium specjalne dla osób niepełnosprawnych, jak i różnego rodzaju zapomogi, z których studenci z niepełnosprawnościami mogą korzystać na takich samych zasadach, jak pozostali. W dalszej kolejności respondenci wymieniają takie formy wsparcia, które wynikają z własnej inwencji uczelni i rozpoznania specjalnych potrzeb studentów. Wiele uczelni wymieniło tu możliwość dostosowania formy egzaminów (wstępnych, semestralnych, końcowych) do specjalnych potrzeb studentów z niepełnosprawnościami (72\%), przy czym najczęściej dotyczy to zamiany egzaminu pisemnego na ustny i odwrotnie, w zależności od możliwości studenta.

Innymi popularnymi działaniami ${ }^{27}$, podejmowanymi przez polskie szkoły wyższe na rzecz niepełnosprawnych studentów są: aktywizacja zawodowa (44\%), pomoc psychologiczna (39\%) oraz możliwość wypożyczenia specjalistycznego sprzętu, pomagającego w studiowaniu (40\%). Rzadziej stosowane rozwiązania to pomoc ze strony uczelni w rozwijaniu umiejętności związanych ze studiowaniem (pamięć, techniki uczenia się, radzenie sobie ze stresem) - 31\%, rehabilitacja i motywowanie do aktywności fizycznej - $26 \%$, podwyższanie umiejętności psychospołecznych - 26\%, zwiększanie mobilności (specjalistyczny transport, asystenci transportowi) - $26 \%$ oraz zapewnienie

26 Ibidem.

27 Ibidem. 
specjalistycznych usług, np. tłumacza języka migowego, tyflopedagoga, surdopedagoga, logopedy i innych $-24 \% .20 \%$ respondentów wskazało na jeszcze inne formy wsparcia, jakie są oferowane na ich uczelniach np. dodatkowe zajęcia usprawniające, indywidualne zajęcia np. lektoraty języka obcego, dodatkowa pomoc osobowa (np. asystenci osób niepełnosprawnych, pomagający podczas zajęć lub w trakcie laboratoriów), organizacja zajęć integracyjnych/adaptacyjnych, dodatkowe usprawnienia sprzętowe (wyposażenie budynków dydaktycznych, systemy nagłaśniające, druk w brajlu i inne).

Realizacja potrzeb studentów z niepełnosprawnościami w coraz większym obszarze, uwzględniająca wszystkie sfery funkcjonowania biopsychospołecznego jest paradygmatem naszych działań i przybliża nas do budowy spójnego, międzyuczelnianego systemu wsparcia studentów z niepełnosprawnościami. Jednym z problemów związanych z udzielaniem pomocy przez biura ds. osób niepełnosprawnych jest zjawisko pojawienia się bierności osoby wspieranej na skutek udzielanego wsparcia. Czasami zbyt wszechstronna lub długotrwała pomoc skutkuje biernością osoby otrzymującej wsparcie. Problem polega na jakości i rodzaju udzielonego wsparcia. Uchwycenie właściwego wymiaru i rodzaju wsparcia nie należy jednak do rzeczy łatwych. Czasami niewielka dawka wsparcia przynosi zaskakująco dobre wyniki, natomiast większa nie przyczynia się do poprawy sytuacji osoby wspieranej, a w najbardziej skrajnych wypadkach prowadzi nawet do jej pogorszenia. rodząc wspomnianą bierność czy nawet pewną formę uzależnienia od ośrodka pomocowego. Ze względu na trudności z każdorazowym dopasowywaniem rodzaju i zakresu wsparcia pomyślano o standaryzacji działań pomocowych. Jednakże standaryzacja, która pojawiła się jako narzędzie eliminujące trudności związane z odpowiednim dopasowaniem formy pomocy niesie i dobre i złe konsekwencje. W ramach tych dobrych można wymienić: szybkość działania, łatwość sięgania po gotową (ustaloną lub nawet zapisaną w systemie organizacyjnym) formę wsparcia, łatwość zachowania równości (ta sama pomoc, przy tych samych trudnościach). Jednakże do słabości systemu - wystandaryzowanych form wsparcia należy: nieadekwatność ustalonej formy wsparcia do potrzeb konkretnej osoby, biurokracja oraz w konsekwencji marnotrawstwo środków. Obok trudności związanych z dopasowaniem formy wsparcia do potrzeb studenta pojawia się także, wspomniany już, problem bierności i uzależnienia. Czasami wsparcie 
od samego początku ma charakter uzależnienia studenta od dalszej pomocy, zamiast zwiększania jego własnej odpowiedzialności za swoje życie. Taka pomoc może przekształcić się nawet w stałe roszczenie wobec danej instytucji lub w przemoc instytucjonalną. Paradoks polega na wykreowaniu zamiast studenta samodzielnego i twórczo rozwiązującego swoje problemy, „dającego” coś społeczeństwu, studenta uzależnionego od kolejnych form pomocy, czyli wyłącznie „biorącego” od społeczeństwa, co w skrajnych przypadkach może doprowadzić do postawy roszczeniowej studenta. Udzielanie wsparcia osobie roszczeniowej, niezdolnej do dialogu, prowadzi z kolei do trudności po stronie pomagającego (czyli pracownika biura ds. osób niepełnosprawnych czy nauczyciela akademickiego), budzi w nim sprzeciw oraz niechęć do udzielania racjonalnego wsparcia i może doprowadzić do nieświadomego zaniechania, co z kolei wzmacnia jedynie postawę roszczeniową oraz skłonność do krytyki tych, których zadaniem jest na uczelni udzielanie wsparcia. Paradoks ten można by określić z perspektywy pomagającego (czyli pracownika biura czy pracownika administracji lub nauczyciela akademickiego) jako wewnętrzny dysonans między nakazem (etycznym czy instytucjonalnym) udzielania pomocy a ryzykiem uzależnienia od siebie studenta, a z perspektywy otrzymującego pomoc jako dysonans między wewnętrzną potrzebą bycia wolnym i decydowania o sobie a koniecznością przyjęcia pomocy dziś, ograniczającej jednak swobodę przyszłych decyzji ${ }^{28}$.

Wsparcie studentów i doktorantów z niepełnosprawnościami powinno być świadczone w sposób przemyślany i dopasowany do indywidualnych potrzeb studenta z niepełnosprawnością przy maksymalnie dobrze rozpoznanej jego sytuacji. Ponadto powinno być uzależnione od efektów wsparcia udzielonego na wcześniejszych etapach edukacji. Odpowiedni pracownicy uczelni, szczególnie pracownicy biur ds. osób niepełnosprawnych, powinni posiadać dobre przygotowanie zarówno merytoryczne, dotyczące znajomości potrzeb osób z daną niepełnosprawnością, jak i choćby ogólne przygotowanie psychologiczne.

28 J. Filek, Rozważania wokół fenomenu pomocy, „Ekonomia Społeczna” 2011, nr 2, s. 7-20. 
Analizując organizację i funkcjonowanie systemu wsparcia studentów z niepełnosprawnościami na przestrzeni ostatniej dekady w Polsce widać pozytywne zmiany w tym zakresie. W 2015 roku w Polsce w toku badań ${ }^{29}$ uzyskano szczegółową informację o formach wspierania osób z niepełnosprawnościami w co 3 szkole wyższej w Polsce. Natomiast w roku $2007^{30}$ wśród 427 publicznych i niepublicznych szkół wyższych około 50\% wszystkich uczelni w Polsce nie posiadało żadnego systemu wsparcia studentów z niepełnosprawnościami.

System wsparcia studentów z niepełnosprawnościami w Polsce jest ofertą pomocy coraz lepiej skonstruowanej i odpowiadającej potrzebom tej grupy osób. Jednak jak pisze prof. Janina Filek ${ }^{31}$ :

Teraz przyszedł czas na pytania: jak to zrobić, aby zrobić to z jednej strony najbardziej efektywnie, ale też z drugiej strony włączyć studenta w proces poszukiwania optymalnej dla niego formy wsparcia, bowiem na drodze pomagania czai się wiele paradoksów, trudności, czy nawet zagrożeń. Rzecz w tym, aby pomoc udzielana studentom polegała na zwiększaniu ich mocy w każdym ze znaczeń tego słowa. Dlatego najlepszym sposobem wsparcia wydaje się wsparcie oparte na elementach integracji społecznej i dialogu.

\begin{abstract}
The right to education is one of the fundamental human rights which enables personal development, independence, and full participation in all spheres of life. Article 70 of the Polish Constitution grants everyone the right to education and obliges public authorities to ensure universal and equal access to education for all citizens. By ratifying the Convention on the Rights of Persons with Disabilities, Poland recognized the right of this group of people to education and committed itself to ensuring an inclusive education system enabling
\end{abstract}

29 Por. J. Sztobryn-Giercuszkiewicz, Formy wspierania studentów...

30 Więcej: Dostępność polskich wyższych uczelni dla osób niepetnosprawnych, raport Fundacji Instytut Rozwoju Regionalnego, Kraków 2007, [w:] Zasada równego traktowania - prawo i praktyka. Dostępność infrastruktury publicznej dla osób z niepetnosprawnościq̨. Analiza i zalecenia, „Biuletyn Rzecznika Praw Obywatelskich”, Warszawa 2015, nr 5.

31 J. Filek, Rozważania wokółform wsparcia studentów niepełnosprawnych, [w:] B. Szczupał, K. Kutek-Sładek (red.), Wielowymiarowość integracji społecznozawodowej studentów z niepełnosprawnością, Uniwersytet Papieski Jana Pawła II w Krakowie - Wydawnictwo Naukowe, Kraków 2016, s. 15-31. 
integration at all levels of education. Poland has also ensured that these people will have access to universal higher education without discrimination, based on the principle of equality. Since 2008 the Office of Persons with Disabilities has been functioning in the Pontifical University of John Paul II in Krakow, which supports disabled students and PhD students of our University.

The development of the Office over the period of more than ten years, applied procedures, and support systems are described in the article.

Additionally, selected programmes and projects of the Institution and external organizations will be presented alongside the Office of Persons with Disabilities as the leading and supportive institution.

\section{Bibliografia}

Byra S., Parchomiuk M., Osobowościowe i społeczne uwarunkowania radzenia sobie ze stresem przez studentów pierwszego roku, Wydawnictwo Uniwersytetu Marii Curie-Skłodowskiej, Lublin 2009.

Byra S., Percepcja wsparcia $i$ osoby wspierajacej studentów niepetnosprawnych, [w:] S. Byra, M. Parchomiuk (red.), Student niepełnosprawny - wybrane konteksty, Wydawnictwo Uniwersytetu Marii Curie-Skłodowskiej, Lublin 2010.

Dostępność polskich wyższych uczelni dla osób niepełnosprawnych, raport Fundacji Instytut Rozwoju Regionalnego, Kraków 2007, [w:] Zasada równego traktowania - prawo i praktyka. Dostępność infrastruktury publicznej dla osób z niepełnosprawnością. Analiza i zalecenia, „Biuletyn Rzecznika Praw Obywatelskich" Warszawa 2015, nr 5.

Filek J., Rozważania wokół fenomenu pomocy, „Ekonomia Społeczna” 2011, nr 2.

Filek J., Rozważania wokół form wsparcia studentów niepełnosprawnych, [w:] B. Szczupał, K. Kutek-Sładek (red.), Wielowymiarowość integracji społecznozawodowej studentów z niepełnosprawnością, Uniwersytet Papieski Jana Pawła II w Krakowie - Wydawnictwo Naukowe, Kraków 2016.

Giermanowska E., Kumaniecka-Wiśniewska A., Racław M.,Zakrzewska-Manterys E., Niedokończona emancypacja. Wejście niepełnosprawnych absolwentów szkót wyższych na rynek pracy, Wydawnictwa Uniwersytetu Warszawskiego, Warszawa 2015.

Konstytucja Rzeczypospolitej Polskiej z dnia 2 kwietnia 1997 r., Dz.U. 1997, nr 78, poz. 48.

Konwencja o prawach osób niepełnosprawnych sporządzona w Nowym Jorku dnia 13 grudnia 2006 r., ratyfikowana przez Prezydenta RP 6 września 2012 r., Dz.U. 2012, poz. 1169. 
Okoń W., Słownik pedagogiczny, PWN, Warszawa 1981.

Sowa J., Bezradność osoby niepetnosprawnej na tle przestrzeni życiowej. [w:] Z. Gajdzica, M. Rembierz (red.), Bezradność. Interdyscyplinarne studium zjawiska w kontekście zmiany społecznej i edukacyjnej, Wydawnictwo Uniwersytetu Śląskiego, Katowice 2005.

Struck-Peregończyk M., Podstawy kadry akademickiej wobec studentów niepetnosprawnych. Studium przypadku Wyższej Szkoły Informatyki i Zarządzania w Rzeszowie, [w:] B. Gąciarz (red.) Niepetnosprawni studenci w społeczności akademickiej. Źródła sukcesów i porażek w integracji społecznej i aktywności zawodowej, Wydawnictwo IFiS PAN, Warszawa 2010.

Szczupał B., Młodzież niepełnosprawna wobec edukacyjno-zawodowej przyszłości, [w:] T. Żółkowska (red.) Pedagogika specjalna-koncepcje i rzeczywistość. Konteksty pedagogiki specjalnej, t. 2, Wydawnictwo Print Group Daniel Krzanowski, Szczecin 2007.

Szempruch J., Edukacja wobec wyzwań i zadań współczesności i przyszłości: strategie rozwoju, Wydawnictwo Uniwersytetu Rzeszowskiego, Rzeszów 2006.

Sztobryn-Giercuszkiewicz J., Formy wspierania studentów z niepełnosprawnościami $w$ szkołach wyższych $w$ Polsce. Raport z badania polskich uczelni, Wydawnictwo Uniwersytetu Łódzkiego, Łódź 2015.

Ustawa z dnia 27 lipca 2005 r. - Prawo o szkolnictwie wyższym, Dz.U. 2005, nr 164, poz. 1365.

Ustawa z dnia 18 marca 2011 r. o zmianie ustawy - Prawo o szkolnictwie wyższym z dnia 18 marca 2011 r., Dz.U. 2011, nr 84, poz. 455.

Żuraw H., Udział osób niepełnosprawnych w życiu społecznym, Wydawnictwo Akademickie Żak, Warszawa 2008.

\section{Netografia}

Education at a Glance 2012: OECD Indicators, OECD Publishing. http:// dx.doi.org/10.1787/eag-2012-en (dostęp: 23.12.2019).

www.unesco.pl/.../Powszechna_Deklaracja_Praw_Czlowieka.pdf (dostęp: 23.06.2018). 